\title{
Performance and Emission Characteristics of Tylosema Esculentum Biodiesel in a Diesel Engine: An Experimental Investigation
}

\author{
Jerekias Gandure $^{1}$, Clever Ketlogetswe ${ }^{1}$ and Abraham Temu ${ }^{2}$ \\ 1. Mechanical Engineering Department, University of Botswana, Gaborone P/Bag UB 0061, Botswana \\ 2. Chemical and Mining Engineering Department, University of Dar es Salaam, Dar es Salaam P. O. Box 35131, Tanzania
}

Received: August 04, 2013 / Accepted: August 27, 2013 / Published: January 31, 2014.

\begin{abstract}
Biodiesel derived from indigenous feed stocks such as Tylosema esculentum kernel oil is deemed a feasible alternative to petroleum diesel for the diesel engine. This paper presents results of investigation of performance and emissions characteristics of diesel engine using Tylosema biodiesel. In this investigation, Tylosema biodiesel was prepared, analyzed and compared with the performance of petroleum diesel fuel using a single cylinder compression ignition diesel engine. The specific fuel consumption, engine torque, engine brake power, hydrocarbons, carbon monoxide and carbon dioxide were analyzed. The tests showed a decrease in engine brake power and torque with increase in engine load, while specific fuel consumption showed an increasing trend with maximum variation of $33 \%$ between the two fuels at engine load of $90 \%$. Emission levels of hydrocarbons, carbon monoxide and carbon dioxide showed an increasing trend with increase in load for both fuels. Tylosema biodiesel produced significantly lower concentrations of hydrocarbons than petroleum diesel, while levels of carbon dioxide and carbon monoxide were largely comparable to those of petroleum diesel. Soot production from combustion of Tylosema biodiesel was found to be approximately $98 \%$ lower than that from combustion of petroleum biodiesel, demonstrating insignificant contribution to environmental pollution.
\end{abstract}

Key words: Tylosema, biodiesel, performance, emissions.

\section{Nomenclature}

$\begin{array}{ll}\text { PD } & \text { Petroleum diesel } \\ \text { B100 } & 100 \% \text { biodiesel } \\ \text { TE } & \text { Tylosema esculentum } \\ \text { ECU } & \text { Electrical control unit } \\ \text { BTDC } & \text { Before top dead centre } \\ \text { ATDC } & \text { After top dead centre } \\ \mathrm{HC} & \text { Hydrocarbons } \\ \mathrm{CO} & \text { Carbon monoxide } \\ \mathrm{CO}_{2} & \text { Carbon dioxide } \\ \mathrm{NO}_{\mathrm{x}} & \text { Oxides of nitrogen } \\ \mathrm{ECU} & \text { Electrical control unit }\end{array}$

\section{Introduction}

Although the concept of using vegetable oil as engine fuel is not new, recent research shows renewed

Corresponding author: Jerekias Gandure, researcher, research fields: biofuels and bioenergy. E-mail: gandurej@mopipi.ub.bw. interest on biodiesel as a suitable alternative fuel for petroleum diesel in diesel engines. This has been exacerbated by increasing cost of petroleum diesel and the negative impact of its emissions on the environment. In this context, many feed stocks for biodiesel production have been proposed, with most vegetable oils being suitable substrates. As a result, there is need for property data for as many biodiesel fuels as possible, based on different oils, to evaluate their suitability for use in diesel engines. Though results of measurements and predictions of some biodiesel properties have been reported [1], Tylosema esculentum oil based biodiesel has not been explored.

Tylosema esculentum (morama bean), also called the desert bean, is a long-lived, perennial, tuberous legume which occurs naturally in extreme environments with high temperatures (typical daily 
maximum of $37{ }^{\circ} \mathrm{C}$ in the growing season), low rainfall (100-900 mm) and long periods of drought [2]. The plant is indigenous to the Kalahari Desert and neighboring areas with poor semi-arid soils in Botswana, Namibia and the northern part of South Africa, but also occurs in Angola, Zambia and Mozambique. Tylosema plant is a creeper with stems up to $3 \mathrm{~m}$ long arising from a large tuber with forked tendrils which facilitate climbing opposite the leaves [3]. The plant typically grows in very sandy loam, where water logging would not be a problem. It produces very hard pods, which usually contain one or two, but sometimes as many as six, large (2-3 g) dark brown edible seeds (Fig. 1a) which in turn contain cream white oil bearing kernels (Fig. 1b). The seed is a neglected and underutilized traditional food, which forms part of the diet for the indigenous population in Southern Africa [2]. In the Kalahari Desert of Botswana, there is a huge abundance of Tylosema bean that lies in waste every year, with an insignificant proportion being eaten by bird species such as the Ostrich and by the Kgalagadi people as a snack.

Though Tylosema seeds are edible, their envisaged potential use as feedstock for biodiesel production is therefore deemed as an appropriate utilization of a neglected resource. This is coupled by its high oil yield (39\%), which is one of the important factors to be considered in identifying potential feed stocks for production of biodiesel. Table 1 compares oil yield level of Tylosema kernels with those of mostly studied plant species obtained from literature.

The comparison of yield levels presented in Table 1 indicates that Tylosema esculentum kernels have a fairly high oil content to justify consideration as a potential feedstock for production of biodiesel. Beside the oil content of Tylosema seed, further exploration may seek to validate the economic viability of the feedstock by establishing the kernel oil produced per unit area. For example, despite the fact that Jatropha curcas oil content is higher than that of palm, the latter

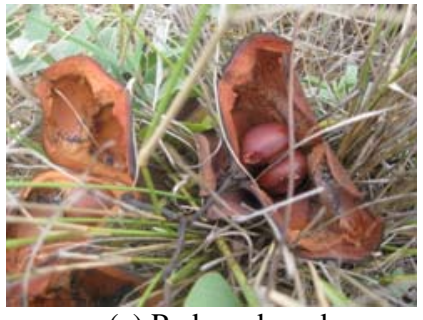

(a) Pods and seeds

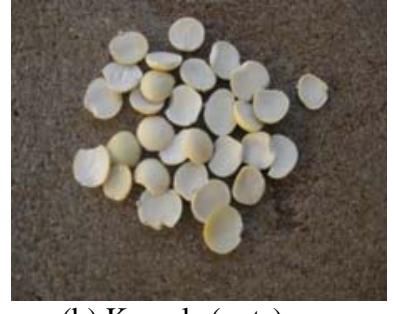

(b) Kernels (nuts)
Fig. 1 Tylosema esculentum.

Table 1 Oil yield levels of Tylosema seeds and common oil seed species.

\begin{tabular}{lll}
\hline Plant species & Yield (\%weight) & References \\
\hline Tylosema esculentum & 39.48 & {$[4]$} \\
Jatropha curcas & ${ }^{1} 63.16 ;{ }^{2} 46.27 ;{ }^{3} 50-60$ & ${ }^{1}[5] ;{ }^{2}[6] ;{ }^{3}[7]$ \\
Linseed & 33.33 & {$[8]$} \\
Soybean & ${ }^{1} 18.35 ;{ }^{2} 20.00$ & ${ }^{1}[8] ;{ }^{2}[9]$ \\
Palm & 44.60 & {$[8]$} \\
\hline
\end{tabular}

produces more oil per hector as shown in Table 2. This however is a weak argument as oil yield varies with factors such as growing conditions (whether optimized or natural) and soil type.

Many experimental studies of biodiesel as an alternative to petroleum diesel have been reported in Refs. [10, 11]. Yet, experimental investigations on effects of Tylosema biodiesel on diesel engine seem not to have been attempted. The major properties of Tylosema biodiesel include calorific value, flash point, cloud point, pour point, specific gravity, acidity and kinematic viscosity. The various physicochemical properties of petroleum diesel and Tylosema biodiesel were measured and are listed in Table 3 for comparison.

It can be noted that the specific gravity and kinematic viscosity are respectively $1.81 \%$ and $4.35 \%$ greater in the case of Tylosema biodiesel than that for petroleum diesel. The higher specific gravity of Tylosema biodiesel makes the fuel to spray narrow and its penetration deeper. The difference in viscosity values between the two fuels may not cause a significant difference on the combustion characteristics such as atomization quality since the values are almost equal in magnitude. From the high cloud and pour points of Tylosema biodiesel fuel, it can 
Table 2 Oil yield per acre of common oil seed species.

\begin{tabular}{lc}
\hline Plant species & Yield (L/ha) \\
\hline Jatropha curcas & 1,892 \\
Linseed & 478 \\
Soybean & 446 \\
Palm & 5,950 \\
\hline
\end{tabular}

Table 3 Comparison of fuel properties between Tylosema biodiesel and petroleum diesel.

\begin{tabular}{llll}
\hline Fuel property & Unit & $\begin{array}{l}\text { Petroleum } \\
\text { diesel }\end{array}$ & $\begin{array}{l}\text { Tylosema } \\
\text { biodiesel }\end{array}$ \\
\hline Kinematic viscosity at $40^{\circ} \mathrm{C}$ & $\mathrm{mm}^{2} / \mathrm{s}$ & 2.3 & 2.4 \\
Specific gravity at $25{ }^{\circ} \mathrm{C}$ & $\mathrm{kg} / \mathrm{m}^{3}$ & 831 & 846 \\
Flash point & ${ }^{\circ} \mathrm{C}$ & 79 & 129 \\
Pour point & ${ }^{\circ} \mathrm{C}$ & -12 & 6 \\
Cloud point & ${ }^{\circ} \mathrm{C}$ & 2 & 8 \\
Acidity & $\mathrm{mgKOH} / \mathrm{g}$ & 0.2 & 0.2 \\
Calorific value & $\mathrm{MJ} / \mathrm{kg}$ & 46.5 & 42.0 \\
\hline
\end{tabular}

be concluded that the fuel has poor cold flow properties. This renders the fuel unsuitable for use in cold climatic regions in its natural state. It is however suitable for use in hot climatic regions such as most parts of Africa and Asia, where temperatures scarcely approach $0{ }^{\circ} \mathrm{C}$. However, the flash point of Tylosema biodiesel is much higher than that of petroleum diesel, making it safer from ignition due to accidental fuel spills during handling. It can be seen that the properties of Tylosema biodiesel are found to be within the limits of American standard test method for biodiesel ASTM
D-6751 and biodiesel specifications of several countries. The calorific value of Tylosema biodiesel is quite comparable to that of petroleum diesel, with a variation of $9.7 \%$.

This work therefore experimentally investigates the performance (specific fuel consumption, brake power and engine torque) and emissions (carbon monoxide, unburned hydrocarbons and carbon dioxide) parameters of Tylosema biodiesel and petroleum diesel as fuel in a compression ignition diesel engine.

\section{Experimental Method}

\subsection{Engine Performance Analysis}

The engine performance test of Tylosema biodiesel and petroleum diesel fuels was conducted on a TD43F engine test rig. The test rig is water cooled four-stroke diesel engine that is directly coupled to an electrical dynamometer as demonstrated in Fig. 2. The dynamometer was used for engine loading. In addition to the conventional engine design, the engine incorporates variable compression design feature which allows the compression ratio to be varied from $5: 1$ to $18: 1$. The layout of the experimental setup is shown in Fig. 2, while engine specifications are presented in Table 4.

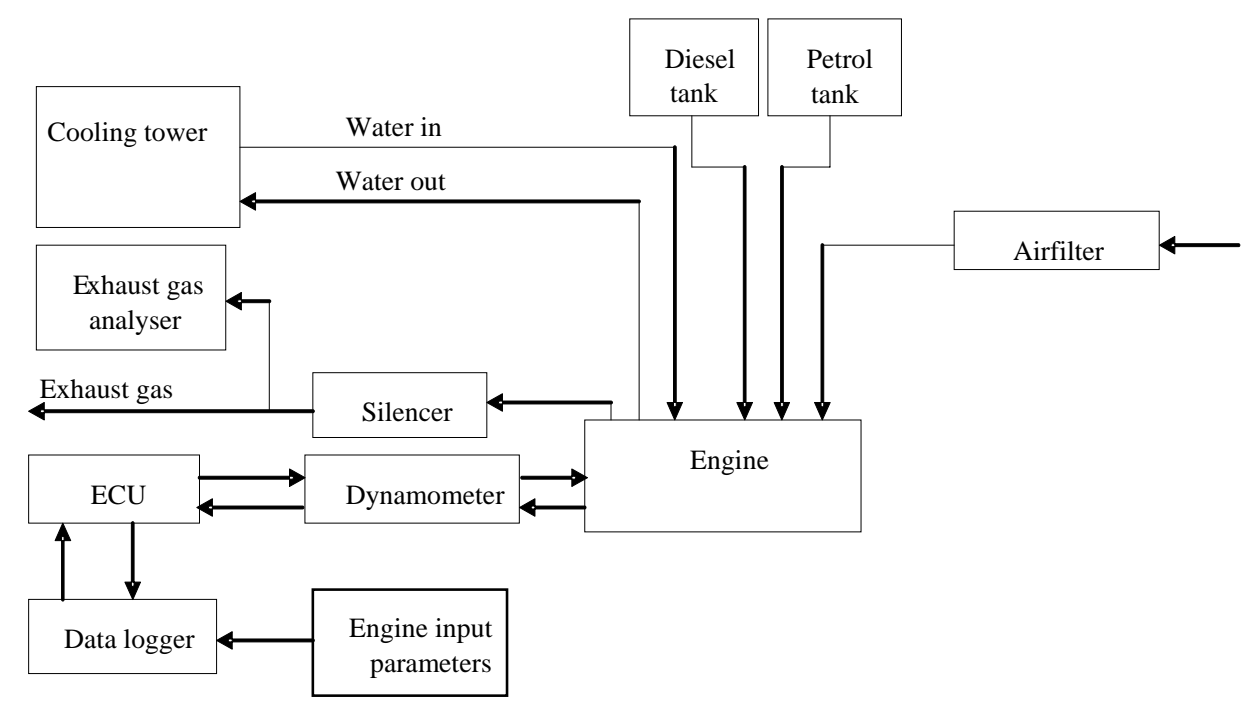

Fig. 2 Schematic diagram of the experimental setup. 
Table 4 Test engine specifications.

\begin{tabular}{ll}
\hline Parameter & Specification \\
\hline Make & Farymann \\
Type & A30 \\
Compression ratio & Variable 5:1 to 11:1 (petrol), 12:1 \\
Number of cylinders & 1 \\
Cylinder bore & $95 \mathrm{~mm}$ (diesel) \\
Stroke & $82 \mathrm{~mm}$ \\
Swept volume & $582 \mathrm{cC}$ \\
Speed range & $1,000-2,500 \mathrm{rpm}$ (2,750 rpm over \\
Max power & speed cut-out) \\
Max torque & $9.5 \mathrm{~kW}$ \\
Ignition timing & $45 \mathrm{Nm}$ \\
Choke sizes & $30^{\circ} \mathrm{BTDC}$ to $10^{\circ}$ ATDC \\
Dynamometer DC motor & $5-7 \mathrm{~kW} \mathrm{2,500} \mathrm{rpm} \mathrm{with} \mathrm{thermostat}$ \\
\hline
\end{tabular}

Source: Ref. [12].

To establish that engine operating conditions were reproduced consistently as any deviation could exert an overriding influence on performance and emissions results, the reproducibility of the dynamometer speed control set points were maintained within $\pm 0.067 \mathrm{~Hz}$ of the desired engine speed. Prior to the data recording, the compression ratio was set to the desired level and the engine speed was set to a maximum of 2,500 revs/min at full throttle. The engine was allowed to run on petroleum diesel fuel under steady state operating conditions, as opposed to transient conditions characterized by the stop-go type of pattern, for approximately 30 min to reach fully warm conditions. This ensures best engine efficiency and effective burning effects of the warm up cycle and to clear out any moisture from the system and exhaust. This also established the engine's operating parameters which constitute the baseline that was compared with the subsequent case when the Tylosema biodiesel was used. After the engine operating temperature had stabilized, the first sets of readings for brake power, engine torque and specific fuel consumption at the maximum speed of 2,500 revs/min were recorded. The dynamometer load was then increased by adjusting the load current control mechanism until the engine speed reduced by steps of $250 \mathrm{revs} / \mathrm{min}$ to a minimum value of $1,000 \mathrm{rpm}$.
For each step, the data for brake power, engine torque and specific fuel consumption were automatically captured onto a PC (personal computer) using the data acquisition software provided by the engine manufacturer. All measurements were repeated three times for each test setting, and the test sequences were repeated three times.

\subsection{Emissions Measurement}

Emissions measurement was carried out using an EMS Exhaust Gas Analyzer (EMS 5002-W\&800) that works on the EMS exhaust gas analyzer system software and the DECS (Driveability and Emissions Calculation Software). At the commencement of engine performance analysis described in Section 2.1, the exhaust gas analyzer was powered, allowed to warm-up for $10 \mathrm{~min}$, and to zero (setting all the gases to zero). The sample hose was then connected, with the probe placed in the tail (exhaust) pipe, and readings were taken at intervals of $250 \mathrm{rpm}$ of engine speed. The technology of this analyzer allows for auto calibration before every analysis and a high degree of accuracy in the analysis of low concentrations of gases found in the engine. The DECS software was used for calculating and analyzing other emissions related engine performance characteristics. For purposes of repeatability, the emission analyzer accuracy and measuring range are shown in Table 5.

\section{Results and Discussion}

\subsection{Performance Parameters}

\subsubsection{Specific Fuel Consumption}

Fig. 3 shows the comparison of effect of load on specific fuel consumption between petroleum diesel and Tylosema biodiesel. It is seen that specific fuel consumption increases with increase in load for both petroleum diesel and Tylosema biodiesel. However, the rate of increase in specific fuel consumption is more during higher loads (from $60 \%$ up to $90 \%$ ) than that of lower loads (below 60\%). Fig. 3 also shows that Tylosema biodiesel performs significantly better 
Table 5 Emissions analyzer accuracy and measuring range.

\begin{tabular}{lll}
\hline Parameter & Accuracy & Range \\
\hline Hydrocarbons $(\mathrm{HC})$ & $4.00 \mathrm{ppm}$ & $0-24,000 \mathrm{ppm}$ \\
Carbon monoxide $(\mathrm{CO})$ & $0.06 \%$ & $0-10 \%$ \\
Carbon dioxide $\left(\mathrm{CO}_{2}\right)$ & $0.30 \%$ & $0-20 \%$ \\
Oxygen $\left(\mathrm{O}_{2}\right)$ & $0.10 \%$ & $0-25 \%$ \\
${ }^{1}$ Nitrogen oxides $\left(\mathrm{NO}_{\mathrm{x}}\right)$ & $1.00 \mathrm{ppm}$ & $0-5,000 \mathrm{ppm}$ \\
\hline
\end{tabular}

Source: Ref. [13].

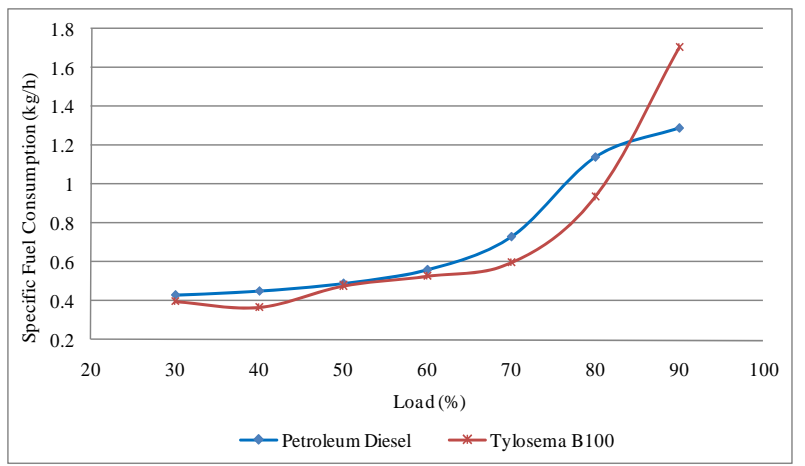

Fig. 3 Specific fuel consumption.

than petroleum diesel in terms of fuel consumption across most engine load settings under review, except for very high settings in the order of $85 \%$ and above. This may partly be due to the higher thermal efficiency of Tylosema biodiesel when compared to fossil diesel, generally attributed to the oxygen content and higher cetane number.

The maximum variation between the two fuels is $33 \%$ at engine load of $90 \%$. The variation of specific fuel consumption also depicts Tylosema biodiesel to be a more economic fuel for the diesel engine than petroleum diesel.

\subsubsection{Engine Torque}

The economic value of Tylosema biodiesel as a fuel in compression ignition engine is further validated by its high engine torque shown in Fig. 4. For both petroleum diesel and Tylosema biodiesel fuels, torque increases to maximum values of $20.1 \mathrm{Nm}$ at load setting of $50 \%$ and $22.4 \mathrm{Nm}$ at load setting of $40 \%$ respectively, and then gradually decreases to minimum values of $10 \mathrm{Nm}$ and $9.2 \mathrm{Nm}$ respectively at engine load of $90 \%$. The disparity in the generated torque can

\footnotetext{
${ }^{1}$ Results for $\mathrm{NO}_{\mathrm{x}}$ emission levels are not reported in this manuscript, they need verification with a different instrument.
}

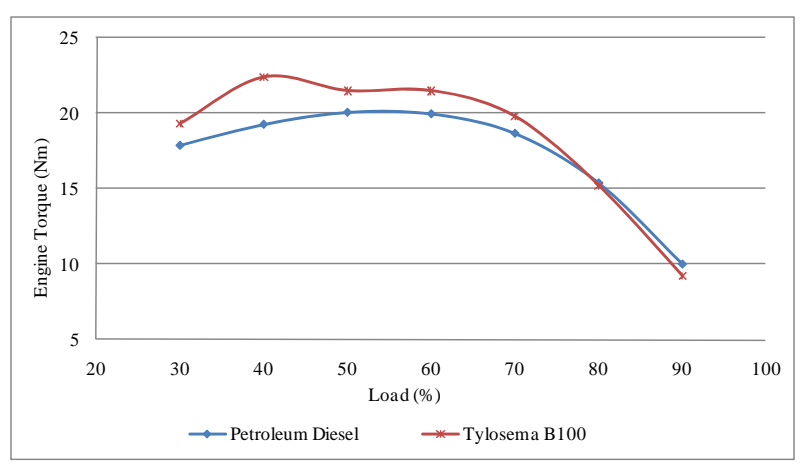

Fig. 4 Engine torque.

be attributed to the improved combustion processes caused by increased atomization and spray characteristics for biodiesel fuel.

\subsubsection{Engine Brake Power}

The brake power profiles shown in Fig. 5 indicate a gradual decrease with increase in engine load for both diesel fuels, with Tylosema biodiesel recording relatively high values when compared to petroleum diesel across the entire engine load settings under review except at $90 \%$. This is consistent with the high torque shown in Fig. 4.

Overall, the results in Figs. 3-5 indicate that Tylosema biodiesel is a suitable fuel for the compression ignition engine, on the basis of performance properties studied. A summary of engine performance using Tylosema biodiesel in comparison with petroleum diesel fuels at a speed of 2,500 rpm and engine load of $30 \%$ is presented in Table 6 .

The exhaust emissions produced from the engine performance analysis are discussed in Section 3.2.

\subsection{Emissions}

This section compares emission levels of unburned hydrocarbon (HC), carbon monoxide (CO) and carbon dioxide $\left(\mathrm{CO}_{2}\right)$ when the engine under review runs on petroleum diesel and on Tylosema biodiesel fuel (B100). The experimental data recorded for the three pollutants are presented in Figs. 6a-6c.

The effect of load on unburned hydrocarbon (HC) emissions for petroleum diesel and neat Tylosema biodiesel is shown in Fig. 6a. One of the most discernible trends connected to the data in Fig. 6a is 


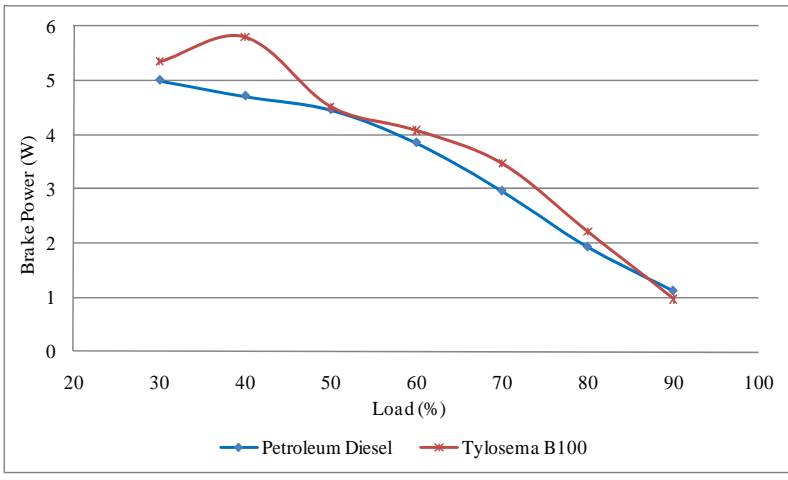

Fig. 5 Brake power.

Table 6 Engine performance using Tylosema biodiesel and petroleum diesel fuels.

\begin{tabular}{lll}
\hline Performance & $\begin{array}{l}\text { Tylosema } \\
\text { biodiesel }\end{array}$ & $\begin{array}{l}\text { Petroleum } \\
\text { diesel }\end{array}$ \\
\hline Brake power $(\mathrm{W})$ & 5.35 & 5.00 \\
Specific fuel consumption (g/kWh) & 0.4 & 0.43 \\
Torque (N) & 19.3 & 17.9 \\
Fuel flow (kg/h) & 2.13 & 2.15 \\
Brake thermal efficiency (\%) & 33.6 & 31.1 \\
Mass of air $(\mathrm{kg} / \mathrm{h})$ & 36.97 & 36.52 \\
Air fuel ratio & 17.36 & 17.01 \\
\hline
\end{tabular}

that combustion of Tylosema biodiesel provides a significant reduction in unburned HC. Lower HC emissions in the exhaust gas of the engine may be attributed to the efficient combustion of Tylosema biodiesel due to the presence of fuel bound oxygen and warmed-up conditions at higher loads.

Figs. $6 \mathrm{~b}$ and $6 \mathrm{c}$ show variation of $\mathrm{CO}$ and $\mathrm{CO}_{2}$ emission levels respectively with increase in engine load.

The data in Figs. 6b and 6c should be viewed and discussed in parallel to enable the correlation between $\mathrm{CO}$ and $\mathrm{CO}_{2}$ emission levels to be identified and explained for the operational conditions under review.

Considering the results in Figs. 6b and 6c, it can be seen that $\mathrm{CO}$ and $\mathrm{CO}_{2}$ emissions of both petroleum diesel and Tylosema biodiesel fuels tend to increase with increase in engine load in a closely comparable pattern. CO is one of the products of incomplete combustion and concentration of oxygen during combustion would enhance the oxidation rate of $\mathrm{CO}$ and lead to less $\mathrm{CO}$ formation. This is a major advantage of oxygenated fuels like biodiesel. However,

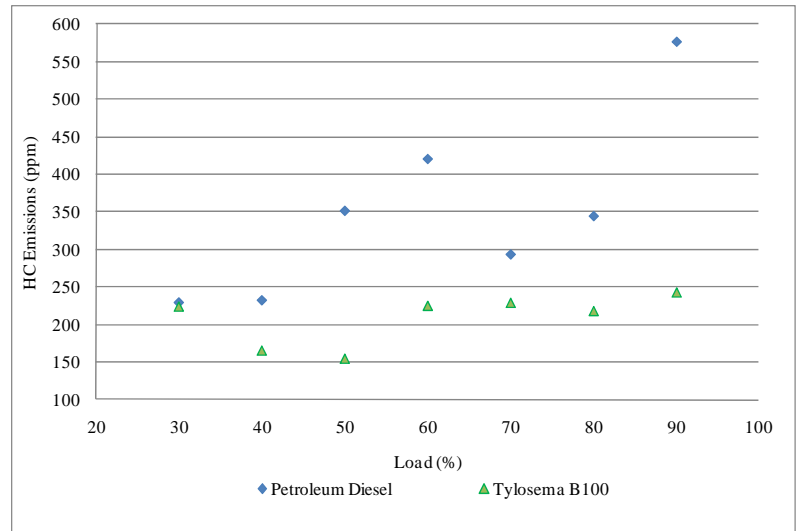

(a) $\mathrm{HC}$

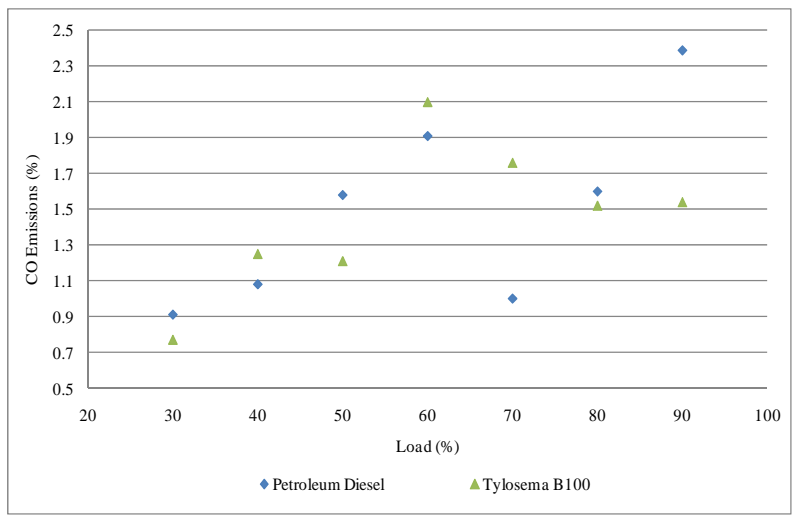

(b) $\mathrm{CO}$

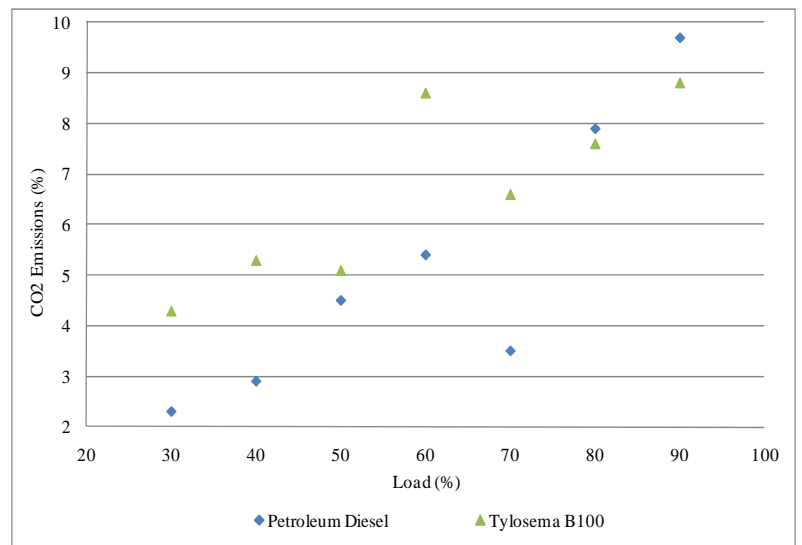

(c) $\mathrm{CO}_{2}$

Fig. 6 (a) $\mathrm{HC}$, (b) $\mathrm{CO}$ and (c) $\mathrm{CO}_{2}$ emissions of the two diesel fuels.

at higher engine loads, the lower temperatures could hinder the conversion rate of $\mathrm{CO}$ to $\mathrm{CO}_{2}$, leading to higher $\mathrm{CO}$ emissions.

Overall results indicate that using Tylosema biodiesel in a compression ignition engine provides significant reduction in HC emission levels than 
petroleum diesel, while levels of $\mathrm{CO}$ and $\mathrm{CO}_{2}$ emissions are quite comparable.

\subsection{Soot Production}

In addition to emission analyses discussed in Section 3.2, it was also observed that the combustion of petroleum diesel fuel produced relatively darker smoke than that from combustion of Tylosema biodiesel. This was validated by measurements of soot produced during combustion of the two fuels in a bomb calorimeter where calorific values of the two fuels were measured. The crucible that was used during the combustion processes was weighed before and after each test run, and the amount of soot produced was determined as presented in Table 7.

Results presented in Table 7 show that combustion of $3 \mathrm{~mL}$ of petroleum diesel and Tylosema esculentum biodiesel produce about $3 \%$ and $0.04 \%$ of soot, respectively. Inferentially, the results indicate that soot production from combustion of petroleum diesel is about $98.7 \%$ higher than that from combustion of Tylosema biodiesel. This is also supported by the proportions of soot deposits on the crucible holder as shown in Fig. 7.

These findings indicate that Tylosema esculentum biodiesel is a clean burning fuel that contributes insignificantly to environmental pollution. The results of soot production analysis appear to agree with observations made by other authors [14] that use of biodiesel reduces engine emissions of particulates, hydrocarbons and carbon monoxide.

\section{Economic Feasibility of Using Tylosema Esculentum as Biodiesel Feedstock}

The future outlook of Tylosema esculentum biodiesel fuel is bright on the basis of abundance and insignificant use for food. As discussed in Section 1, Tylosema esculentum plant is abundant in the Kalahari Desert of Botswana where an insignificant amount of its seeds are eaten by few species of birds such as ostrich, and Kgalagardi people as a snack. Vast quantities of fruit seeds are left to rot annually as an
Table 7 Soot production by the two diesel fuels.

\begin{tabular}{lllll}
\hline Fuel & $\begin{array}{l}\text { Volume } \\
(\mathrm{mL})\end{array}$ & $\begin{array}{l}\text { Mass of } \\
\text { fuel }(\mathrm{g})\end{array}$ & $\begin{array}{l}\text { Mass of } \\
\text { soot }(\mathrm{g})\end{array}$ & $\begin{array}{l}\text { Soot in 3 mL } \\
\text { of fuel (\%) }\end{array}$ \\
\hline PD & 3 & 2.6136 & 0.0810 & 3.10 \\
TE B100 & 3 & 2.7462 & 0.0012 & 0.04 \\
\hline
\end{tabular}

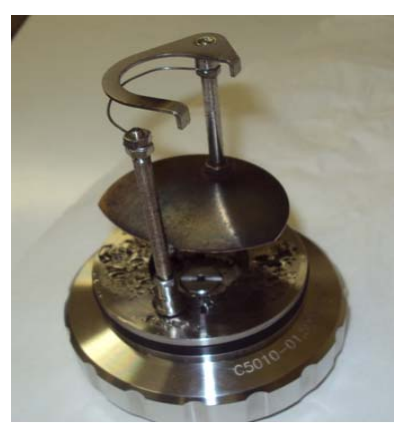

(a)Tylosema biodiesel soot

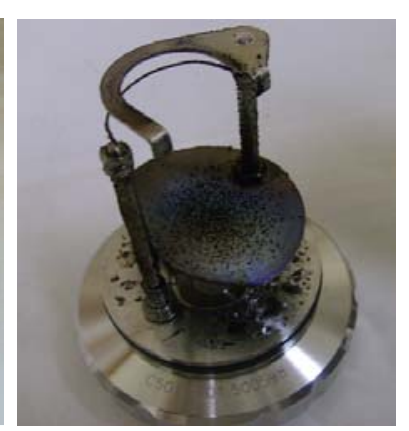

(b) Petroleum diesel soot
Fig. 7 Soot production by the two diesel fuels.

untapped resource. In the production of biodiesel, a major economic factor to consider with respect to input costs is the feedstock, which is estimated at approximately $80 \%$ of the total operating cost [15]. Other important costs relate to the geographical area of the feedstock, variability in crop production from season to season, labor and production inputs including methanol and catalyst. These costs depend on the prices of the biomass used and the size and type of the production plant. Other important factors that would impact the production cost of Tylosema biodiesel are the yield and value of the byproducts of the biodiesel production process, such as oilseed cake (a protein-rich animal feed) and glycerine (used in the production of soap and as a pharmaceutical medium). Since Tylosema kernel oil has not been studied as a potential feedstock for production of biodiesel, precise production costs are yet to be established.

This study aims to establish technical properties of biodiesel as a suitable alternative fuel for the compression ignition engine, thereby providing a basis upon which socio economic feasibility analysis can be done to further the research. Factors including actual yield of Tylosema seeds per hectare and associated production and logistics costs will need investigation. Production of biodiesel from Tylosema esculentum will however have other obvious social impacts. It is a 
potential source of income and employment for many families through gathering and processing of the raw material into biodiesel. Thus, the logistics of harvesting the raw material is deemed simple and cost-effective. Furthermore, the fact that Tylosema esculentum plant thrives and produces abundantly under natural (unoptimised) conditions implies a substantial reduction in overall costs of producing biodiesel from this plant species. Optimizing growing conditions, if desired, may increase the yield.

On the basis of abundant availability and the results discussed in this manuscript, Tylosema esculentum biodiesel is recommended for production in Botswana.

\section{Conclusions}

The following conclusions can be made from the experimental work discussed in this manuscript:

Contrary to common knowledge from literature, the performance of CI (compression ignition) diesel engine using Tylosema biodiesel fuel was found to be marginally better than that using petroleum diesel in terms of fuel consumption, engine torque and break power. Specific fuel consumption, for example, has a maximum variation of $33 \%$ and a minimum variation of $2 \%$ between the two fuels.

The level of HC emissions produced from combustion of Tylosema biodiesel was significantly lower than that of petroleum diesel with a maximum variation of $58 \%$ (at engine load of $90 \%$ ) and a minimum variation of $2 \%$ (at engine load of $30 \%$ ). Emission levels of $\mathrm{CO}$ and $\mathrm{CO}_{2}$ gases produced from combustion of the two diesel fuels were largely comparable.

Soot production from combustion of petroleum diesel was found to be approximately $98 \%$ higher than that from combustion of Tylosema biodiesel. This demonstrates that Tylosema biodiesel is a clean burning fuel with insignificant contribution to environmental pollution.

Overall, Tylosema biodiesel fuel used in this study was at the least comparable to petroleum diesel in terms of fuel properties and performance, and is recommended for use in CI diesel engines.

\section{Acknowledgments}

The authors acknowledge support of the University of Botswana, and the Ministry of Wildlife, Tourism and Environment who granted a research permit for this work.

\section{References}

[1] Y.D. Wang, T. Al-Shemmeri, P. Eames, J. McMullan, N. Hewitt, Y. Huang, et al., An experimental investigation of the performance and gaseous exhaust emissions of a diesel engine using blends of a vegetable oil, Applied Thermal Engineering 26 (2006) 1684-1691.

[2] H. Mette, H. Soren, H. Ase, Chemical composition of marama bean (Tylosema esculentum)—A wild African bean with unexploited potential, Journal of Food Composition and Analysis 23 (2010) 648-657.

[3] S. Castro, P. Silveira, A. Coutinho, E. Figueiredo, Systematic studies in Tylosema (Leguminosae), Botanical Journal of the Linnean Society 147 (2005) 99-115.

[4] J. Gandure, C. Ketlogetswe, Assessment of potential for biodiesel feedstock of selected wild plant oils indigenous to Botswana, Energy and Environment Research 1 (2011) 61-66.

[5] E. Akbar, Z. Yaakob, S.K. Kamarudin, M. Ismail, J. Salimon, Characteristic and composition of jatropha curcas oil seed from Malaysia and its potential as biodiesel feedstock, European Journal of Scientific Research 29 (2009) 396-403.

[6] A. Joshi, P. Singhal, R.K. Bachheti, Physicochemical characterization of seed oil of jatropha curcas collected from Dehradun (Uttarakhand) India, International Journal of Applied Biology and Pharmaceutical Technology 2 (2) (2011) 123-127.

[7] X.Q. Guo, C.Y. Sun, S.X. Rong, G.J. Chen, T.M. Guo, Equation of state analog correlations for the viscosity and thermal conductivity of hydrocarbons and reservoir fluids, Journal of Petroleum Science and Engineering 30 (2001) 7-15.

[8] F.D. Gunstone, The Chemistry of Oils and Fats: Sources, Composition, Properties and Uses, Blackwell Publishing Ltd., London, 1994.

[9] A. Hou, P. Chen, A. Shi, B. Zhang, Y.J. Wang, Sugar variation in soybean seed assessed with a rapid extraction and quantification method, International Journal of Agronomy 2 (2009) 1-8. 
[10] V.S. Yaliwal, S.R. Daboji, N.R. Banapurmath, P.G. Tewari, Production and utilization of renewable liquid fuel in a single cylinder four stroke direct injection compression ignition engine, International Journal of Engineering Science and Technology 2 (2010) 5938-5348.

[11] M.L.J. Martin, V.E. Geo, D. Prithviraj, Effect of diesel addition on the performance of cottonseed oil fuelled DI diesel engine, International Journal of Energy and Environment 2 (2011) 321-330.
[12] TecQuipment Ltd. Home Page, United Kingdom, NG10 2AN, www.tecquipment.com (accessed Jan. 17, 2010).

[13] EMS Home Page, USA, www.emsgas.com (accessed May 3, 2012).

[14] M.S. Graboski, R.L. McCormick, Combustion of fat and vegetable oil derived fuels in diesel engines, Progress in Energy and Combustion Science 24 (1998) 125-164.

[15] A. Demirbas, Progress and recent trends in biodiesel fuels, Energy Conversion and Management 50 (2009) 14-34. 